\title{
Distribution and Characteristics of Early Man
}

$\mathrm{I}^{\mathrm{N}}$ celebration of the one hundred and twenty-fifth anniversary of the founding of the Academy of Natural Sciences of Philadelphia, an international symposium on early man was held at the Academy on March 17-20, when a number of representative archæologists from all parts of the world were present. In addition to the introductory address by Dr. John C. Merriam, president of the Carnegie Institution of Washington, and chairman of the committee for the symposium, thirty-two communications were presented, and four round-table discussions on problems of chronology and distribution took place. Broadly, the programme was arranged so that the communications presented on each day dealt with the problems of a continental area: on March 17 communications dealing with Europe or bearing on general problems of correlation with European cultures, on March 18 communications concerned with America, on March 19 matters relating to Asai and the Pacific and general problems arising out of the evidence therefrom, and on the closing day a small group of miscellaneous communications. The proceedings closed with a review of the problem of early man, based on the communications presented at the symposium, by Dr. G. Grant McCurdy.

In the following report mention is made only of the communications of wider general interest.

The proceedings on March 17, following on the introductory address, opened with a communication by Dr. G. H. R. von Koenigswald reviewing man's geological record in Java, and this was followed by a survey of the palæolithic industries of China by Mr. W. C. Pei, which suggested some striking correlations with the palæolithic industries of Europe. The most ancient artefacts of China identified by Abbé Breuil are the Nihowan, a piece of worked stone and some pieces of worked bone, in geological age Upper Pliocene and equivalent to the Villafranchian of Europe. Locality 13 industry, represented by a chert implement of undoubted human origin, corresponds to the Abbevillian of France and geologically is attributed to an early phase of Lower Pleistocene. Of the four main industries of China, Sinanthropus, which begins the true industry of China, is also attributed to the Abbevillian and the Lower Pleistocene; the newly discovered and as yet little studied Locality I5 industry of Choukoutien, of the early Middle Pleistocene, corresponds to the Late Lower Palæolithic of Europe; the Ordos industry, contemporary with part of the Chinese loess, belongs to the late Middle Pleistocene; and the Choukoutien Upper Cave industry, which is the Upper Palæolithic of China, corresponds to Aurignacian, Solutrean and Magdalenian.

Two communications came from Palestine. Miss Dorothy Garrod dealt with "The Near East as a Gateway of Prehistoric Human Migrations" and Sir Arthur Keith and Mr. Th. McCown, in a joint communication read by the latter, reported on the early human skeletal remains from Palestinian caves on Mount Carmel. It was pointed out that the human remains from the Levallois-Mousterian layers of these caves not only provide new additions to the considerable list of fossil specimens of man from the middle part of the Stone Age, but they also provide a new perspective concerning Neanderthal man, present a new type of humanity, which is the probable stock ancestral to the inhabitants of Europe in late Palæolithic times, and place in a new orientation the central problem of the evolution of the modern races of man.

The stratigraphic culture sequence in the three Wady Mughara caves overlaps in such a manner that the record carries us from the Acheulean, through the Levallois-Mousterian, to the Aurignacian and culminates in the Natufian, a new epi-palæolithic culture. The human inhabitants of the caves are represented from the Levallois-Mousterian and the Natufian periods.

Three and a half years intensive work on the bones of the Mousterian peoples of Mugharet es-Skhul and el-Tabun has led finally to the conclusion that we here have two distinct types of man, both living in Palestine at about the same time, and before the marked change in the character of the Pleistocene fauna and in the climate which are to be related with the period of the last glaciation in Europe. Mount Carmel man is certainly pre-Würmian.

The first type is represented by a young adult woman of small stature $(1520 \mathrm{~mm}$.) from el-Tabun. The skull is small and low with a heavy frontal torus, the mandible is chinless and the face prognathous. The pelvis, especially the pubic parts, exhibits primitive anthropoid features not seen heretofore in any human race. This is a type similar to, but not identical with, the Western European Neanderthalians; at the same time it bears an unmistakable relationship to the Skhul people.

The other type of Mount Carmel man comes from the Mugharet es-Skhul. The material consists of two tall adult males, $1738 \mathrm{~mm}$. and $1780 \mathrm{~mm}$., that is, nearly or quite six feet. Their lower limb bones in measurement are closest to those of the tall Cromagnon males. Other parts of the skeleton corroborate with varying emphasis. The large well: vaulted skulls exhibit frontal tori with greater or lesser degrees of development, the large palate protrudes, and is completed by a mandible with a clearly defined chin and a modern internal conformation to the symphysis. The teeth do not show the taurodont condition of Neanderthal man, nor indeed do those of the Tabun type. The teeth of a wellpreserved child, as well as of other young individuals, show unmistakable traces of a primate ancestry.

In all there are the remains of ten individuals on which conclusions are based. One of the most important points to emerge is their great variability. Their anatomical characters fall into three categories. In the first group, which is small, are the characters like those of the Western European Neanderthals; in the second, slightly larger, are intermediate characters between those of Neanderthal and of Neanthropic man; and the third, which contains by far the greater number, comprises the characters similar to those found in the Upper Palæolithic inhabitants of Europe, leading to the conclusion that there is a genetic relation between the ancient Palestinians and the Cromagnons. In reviewing the 
evidence as a whole, it may be said that the Skhul people are at least contemporaries, and possibly considerably earlier than the men of La Chapelle, La Ferrassie, of Spy and Neanderthal. They bear the imprint of characters inherited from a type ancestral both to themselves and to the European Neanderthalians. These new fossils show conclusively that the Western European Neanderthals were not ancestral to the modern races of mankind; they clearly demonstrate for the first time that evolution was well advanced in the different groups of Homo sapiens in the middle Pleistocene. "Chronologically the Skhul people are too recent and physically they are too distinctive to serve as a form ancestral to Homo sapiens in the widest sense of that term. They do provide us with a variety of man who may be considered as the prototype of the earliest modern Europeans"

More immediately based upon the European evidence relating to early man was a communication by Prof. A. W. Brøgger, dealing with the extension in distribution of late Palæolithic man to the extreme north in northernmost Norway. The remainder of the first session was devoted to the application of recent developments in method in European archæology to American conditions.

In the American session on March 18, the number of communications offered was considerable, opening with Dr. A. Hrdlička's discussion of early man in America in the light of the skeletal evidence. Chronological problems were discussed by $\mathrm{Mr}$. Herbert $\mathrm{J}$. Spinden, and Dr. Ernst Antevs dealt with climate and early man. The Folsom problem received attention from Dr. Frank H. Roberts and others, and several communications dealt with the question of the evidence of geology and palæontology. Mr. Edwin $\mathrm{H}$. Colbert on the pleistocene mammals of America and their relation to Eurasian forms argued for a considerable interchange in pliocene and pleistocene times, with eventually a much later survival in America of certain typical pleistocene forms, such as mammoth, camel, horse, extinct bison and sloths, into recent times.

On March 19 communications dealing with the prehistory of Asia were taken, opening with a contribution by $\mathrm{P}$. Teilhard de Chardin dealing with the Late Cenozoic relations of North China, Malaysia and Central Europe, in which the entry of Sinanthropus into China, probably from the south, was shown to follow an eastern Asiatic uplift which was responsible for changes in earth surface, climate and fauna, and a review of the traces of fossil man in Mongolia by Prof. C. Charles P. Berkey, of Columbia University.

A communication by Prof. V. Gordon Childe, reviewing the evidence relating to the North Eurasian Forest Culture in the Mesolithic and Neolithic phases, drew an interesting parallel between the conditions, which had to be faced by the hunting peoples of northern Europe from Britain to the Urals at about 7000 B.C. with those which had confronted the aboriginals of north America in comparable zones. This forest culture, the Maglemosean, had adapted itself to specialized forms of hunting and fishing, using dog-sleighs (runners found in boreal peat in Finland are the oldest dated evidence for any vehicle for the use of man) conical arrow-heads for killing fur animals, and ice-picks. This East Maglemosean equipment is found right across Central Russia, where, however, it seems to be post-boreal and may mark local survivals of a boreal extension of the Maglemosean. With the more favourable climatic conditions around Denmark of the Littorina trans. gression, the Ertebølle shell-mound culture is to be regarded as an adaptation of the Maglemose to new conditions, its pottery being due to the foreign in. fluences, which afterwards produced the Nordic neolithic cultures of north Germany, Denmark and southern Sweden. East of the Baltic the environ. mental change was insignificant, and the old economy persisted. Later in Finland the hunting and fishing economy was transformed by battle-axe folk, who introduced agriculture and stock breeding. The same transformation was effected in central Russia by the Fatyanovo battle-axe folk, yet there pit-comb pottery survived into the Iron Age after 800 B.C. In the Urals late sub-boreal peats have yielded pottery like the Finnish and Central Russian neolithic wares and the aforementioned bone-work of Maglemosean character. Thanks to such survivals, the makers of pit-comb pottery and so also their Maglemosean ancestors can be linked up with the historical Finno-Ugrian peoples.

A more remote problem was considered by Milo $\mathbf{S}$. Hellman and Prof. W. K. Gregory, in examining the evidence of dentition in its bearing on the origin of man in the light of the new anthropoid ape material obtained in the Siwalik Hills, North India, by Dr. de Terra and Mr. G. E. Lewis. The communication was limited to two problems, the origin of the Dryopithecus pattern of the lower molar crowns and the known limits of variation of that pattern in fossil and recent anthropoids, and its transformation into the cruciate or four-cusped pattern in the more advanced lower molars of man. Among the con. clusions put forward may be mentioned that whilo the Dryopithecus pattern is subject to extreme variation in regard to proportions, it is constant in the fundamental arrangement of the five principal cusps and the several grooves at their base; that of all the variations of the pattern, that of the first lower molar of Australopithecus is the closest to the human modification of the Dryopithecus pattern, though the tooth itself is far too broad to give rise to that of man; that of the known human first lower molars, that of the palæoanthropic division of man, especially of the Ehringsdorf child and Sinanthropus, are the least modified away from the Dryopithecus pattern; and finally, contrary to most authors, the opinion is expressed that the older palæoanthropines are at least structurally ancestral on one hand to Homo neanderthalensis and on the other to Homo sapiens.

In this connexion much interest is attached to certain conclusions at which Dr. H. de Terra has arrived as a result of his investigations in the Siwalik Hills. He states that there is evidence to show that the late tertiary mammals of India migrated to south-east Asia, guided by a shifting of the tropical belt from north to south. It was siggested that such migration should be considered as a major factor in human evolution so far as Asia is concerned. The stone age records of early man in India indicate a great expansion of the old palæolithic races from southern India to the Siwalik Hills in the middle pleistocene, shortly after the Himalayan glaciers had retreated from their second major advance. Towards the close of the Ice Age, another group of stone manufacturing people invaded the lower Indus valley, settling in a region which recent investigation shows to have also an advanced civilization 5,000 years old. Hence the Indus valley shares with other large drainage areas a long tradition of human pre-history. 